\title{
Scientists must conquer reluctance to speak out
}

When science is under political assault, keeping a dignified silence is counterproductive.

Sir - We read with some concern the views of M. J. Hsu and G. Agoramoorthy in Correspondence, that "Scientists and teachers should ignore politics" (Nature 431, 627; 2004). They argue that scientists help society most effectively through teaching and research, rather than by taking part in election campaigns. In the current political climate in the United States, this well-intentioned argument represents a grave threat to both science and society.

The politicization of science threatens to undermine the value of science to society by obscuring scientific consensus and misleading policy-makers and the public. Although the threat is external and most apparent in the suppression and manipulation of science by the Bush administration - the resolution is largely internal. More than 5,500 scientists have signed the Union of Concerned Scientists' statement of protest, and more than 1,800 environmental scientists have signed a separate statement at www.scienceinpolicy. org. But it will take a greater outcry from the scientific community to bring this issue to the prominence it deserves. Scientists must step forward to protest against the manipulation of their results, or the obfuscation of accepted science will become an enduring tactic in political manoeuvring.
Already, scientific information is often clouded in the public arena. Evidence from competing expert witnesses in court cases, for example, makes it difficult for juries to decipher scientific evidence.

Attempts at journalistic balance similarly give equal weight to ideas that have unequal scientific support. This practice - which is neither good journalism nor an effective presentation of scientific knowledge - often creates the misconception that there is serious scientific debate about a particular issue when, in reality, there is virtually none.

For example, journalists gave roughly equal attention to the views of isolated scientists, including those funded by stakeholding industries, long after the wider scientific community reached consensus over the health threat posed by smoking and over the likelihood of human-induced climate change. In the former case, outcry from physicians and scientists finally penetrated the disinformation campaign by the tobacco industry (to society's great benefit). Yet in the climate-change arena, the naysayers still have a significant voice despite the consensus against them.

Politicians increasingly employ a similar misrepresentation of science in public policy debates. If such manipulation is allowed to continue, scientists' constructive provision of unbiased, realistic assessments to policy-makers will be compromised.

Unfortunately, calling on scientists to defend their work from political manipulation bumps squarely against a deep reluctance among scientists to appear partisan. After all, the impartiality of science is largely responsible for the confidence most Americans have in scientific information. Scientists are legitimately concerned that advocacy may undermine the public perception that scientists are relatively apolitical and concerned primarily with facts. But what use is a voice that is held in high esteem but never raised?

We argue that the current assault on science sufficiently threatens the role of science in society to merit the risk of speaking out. Advocacy is less dangerous than sitting quietly on the sidelines while politicians and interest groups undermine the scientific method by perpetrating junk science.

Stephen Porder ${ }^{\star}$, Kai M. A. Chan $\dagger$, Paul A. T. Higgins $\ddagger$

* Department of Biological Sciences, Stanford University, Stanford, California 94305-5020, USA $\dagger$ Center for Conservation Biology, Department of Biological Sciences, Stanford University, Stanford, California 94305-5020, USA

$\$ 151$ Hilgard Hall, University of California, Berkeley, California 94720-3110, USA

\section{Why leave it to others to speak up about science?}

Sir - Your correspondents M. J. Hsu and G. Agoramoorthy (Nature 431, 627; 2004), seem to deny to scientists a right that lawyers, financiers, writers and even movie stars claim for themselves, which is direct involvement in political processes.

If this was ever a wise policy it is surely no longer, when science is so often the pawn of politics and individual politicians. The law on stem-cell research, for example, varies from one country to another according to political dogma. As a postgraduate researcher at a British university, I urge scientists to spare such time as they can afford to be involved with politics as I have done myself, serving on a local council and even standing for parliament.

There is no good reason why lawyers and movie stars should have an exclusive right to debate science matters, any more than scientists should have the final say in the film industry or the law.

The fewer impenetrable membranes with which scientists surround themselves and their work, the better.

Ian Flintoff

22 Chaldon Road,

London SW6 7NJ, UK

\section{Knowledge is a good base to campaign from}

Sir - M. J. Hsu and G. Agoramoorthy in Correspondence (Nature 431, 627; 2004) imply that anybody choosing a career in science or education should disenfranchise themselves, and that a Nobel prize in a field other than peace equals a ban on political campaigning.

I wonder how the two correspondents think the celebrated American chemist Linus Pauling won his second Nobel: the 1962 peace prize? Surely, after being awarded his first one, in chemistry (1954), he should have stayed in his laboratory, setting his mind on loftier, 'scientific' matters, rather than meddling with such mundane business as international relations and public affairs.

By campaigning to halt nuclear testing in the atmosphere, Pauling was both applying his technical expertise and following in the footsteps of others, including Albert Einstein (a pacifist who campaigned against nuclear weapons), who did not see their role in politics as limited by their Nobel prizes.

In the 1950s, Pauling paid the price for his peace campaigns, undergoing hours of interrogation and being refused the right to travel outside the United States. Although Einstein backed him, few other people dared to speak out during a period when an accusation of 'un-American activities' could cost them their livelihood or their freedom.

We do not have to repeat the lesson. Scientists should campaign in politics, and vigorously. I suspect Alfred Nobel, who instituted prizes not only in the sciences but also for peace, would approve.

Kaihsu Tai

Department of Biochemistry,

University of Oxford,

Oxford OX1 3QU, UK 